\title{
ASSESSMENT OF RICE AND MAIZE BASED CROPPING SYSTEMS FOR RURAL LIVELIHOOD IMPROVEMENT IN NEPAL
}

\author{
Pradyumna Raj Pandey (MSc) ${ }^{*}$, Hemprabha Pandey (MA) and Mitsuhiro Nakagawa (PhD)
}

\begin{abstract}
This paper explores the assessment of rice and maize base cropping system in agro-ecological regions for sustainable rural livelihood development in Nepal. Analysis of 1994-2007 data showed rice-dominated cropping systems in the Plain region, as opposed to maize-dominated cropping systems in the Mountain and the Hill regions. The production increase was achieved mainly through increases in area. The growth in the yield of crops was very minimal in all three regions. During the last fifteen years, the cropping pattern changed slightly from Maize-Wheat to Maize-Paddy in the Mountain region, but no significant change was observed in the other two regions. The current rate of fertilizer application is lower than the recommended rate. Improved access to and availability of agricultural inputs is key to improve the production and yield of major food crops to achieve sustainable rural livelihood in the country.
\end{abstract}

Key words: Agro-ecological-region, cropping system, farm income, rural livelihood, sustainable livelihood

\section{INTRODUCTION}

In different literature the definition of cropping systems may vary, however, in general cropping systems refers to the pattern of crops taken up for a given piece of land, or sequence in which the crops are cultivated on piece of land over a fixed period and their interaction with farm resources and other farm enterprises. According to Department of Agriculture, Government of Kerala, India, the cropping system is the cropping pattern used on a farm and its interactions with farm resources, other farm enterprises, and available technology which determine their makeup. However, cropping pattern is the yearly sequence and spatial arrangement of crops and fallow on a given area. Rice, maize and wheat are the major crops of Nepal. Farming systems and crop production in Nepal vary across the agro-ecological regions. Rice-based cropping systems, with wheat or maize as a secondary crop, are predominant in the Plain (Terai) and middle hills, whereas in the high mountains maize, millet, barley and buckwheat are cultivated. Tea, cardamom, ginger and coffee are the important cash crops of the middle hills. Likewise, wide ranges of temperate fruits in the high mountains; citrus in the middle hills; tropical/subtropical fruits are also grown in the Plain (Terai) and middle hill valleys. Vegetable-growing in kitchen gardens is practiced at all elevations (FAO, 1996). Although these major food crops are highly important for maintaining food security and supporting livelihood, the yield performance of these crops is much less than satisfactory. The yield of major food crops in Nepal in recent years has also been lower than other South Asian countries (see Table 1).

Nepal's agricultural production is characterized by diversity in farming systems influenced by differences in agro-ecological topography. Farming systems and crops vary widely depending upon altitude and climatic conditions. The agricultural sector contributed 40.22\% to the Gross Domestic Product in 1995/96 (CBS, 1996). A large majority of households depend upon agriculture and allied activities such as livestock-rearing and forest product collection. As the agriculture sector is the key sector of the economy, determining economic growth and employment, the standard of living of the majority of the population depends on its development. Despite investment in irrigation and agricultural development projects, agriculture production is still largely determined by favourable weather conditions (EIU, 1997). 
Table 1. Paddy, maize and wheat yield and fertilizer application in south Asian countries (IFA/IFDC/PPI/IPI/FAO, 2002 and FAOSTAT, 2005).

\begin{tabular}{lccc|ccc}
\hline Country & \multicolumn{3}{c|}{ Yield* $(\mathrm{t} / \mathrm{ha})$} & \multicolumn{3}{c}{ Fertilizer use $^{* *}(\mathrm{~kg} / \mathrm{ha})$} \\
\cline { 2 - 7 } & Paddy & Maize & Wheat & Paddy & Maize & Wheat \\
\hline Bangladesh & 3.85 & 5.21 & 1.78 & 97 & 48 & 63 \\
India & 3.18 & 2.00 & 2.63 & 101 & 49 & 135 \\
Nepal & 2.69 & 2.05 & 2.12 & 71 & 42 & 77 \\
Pakistan & 3.18 & 3.04 & 2.62 & 59 & 68 & 138 \\
Sri Lanka & 3.73 & 1.54 & - & 143 & 84 & - \\
\hline
\end{tabular}

*Three years' average from 2005 to 2007, ${ }^{* *}$ whole fertilizers in the year of 2002

Agriculture occupies an important place in the economy and politics of many countries of the Asian and Pacific region. In 1992, for example, its contribution to the GDP among the developing countries of the Asian and Pacific region was generally upwards of $25 \%$, rising to $62 \%$ in Nepal (ADB, 1992); and it provides employment to a significant proportion of the total labor force in many countries. In Japan, South Korea, and Taiwan, while agriculture's contribution to the GDP is under $10 \%$ (only about $4 \%$ in Taiwan), many city dwellers maintain their roots in the countryside, where parents or other close relatives still live on ancestral land. And while the economy of the latter countries is tied to industrial development, governments are struggling to find strategies to maintain a balance between industrial development and agricultural stability. Their buoyant economies notwithstanding, they are concerned about issues of food and agricultural security as they import increasingly larger quantities of food and other agricultural products. They are also concerned about the possible environmental and psychological effect of the gradual disappearance of vegetation (OECD, 1988).

The Nepalese economy is primarily agriculture based. The agriculture sector accounts for $33 \%$ of GDP and over $65 \%$ of the economically active population depends on it. Poverty is much more severe in rural areas (42\%) than urban areas $(10 \%)$ and is particularly severe in the mountain agro-ecological region (CBS, 2007). About $80 \%$ of the rural population aged over 15 is engaged in agriculture. The level of income in Nepal is lower than other south Asian countries (see Table 2).

Table 2. Development indicators in South Asia (World Bank, 2004)

\begin{tabular}{l|l|c|c|c|c|c}
\hline \multicolumn{1}{c|}{ Indicator } & \multicolumn{1}{|c|}{ Unit } & Nepal & Bangladesh & India & Pakistan & Sri Lanka \\
\hline GDP per capita & US \$ & 241 & 396 & 493 & 518 & 899 \\
Poverty & \% of total population & 31 & 50 & 29 & 33 & 25 \\
AGDP & \% of total GDP & 33 & 23 & 23 & 23 & 20 \\
\hline
\end{tabular}

The country is divided into three agro-ecological regions namely Mountain in the north, Hill in the middle, and Plain in the south. According to Pariyar (2005), the Mountain region is characterised by higher elevation $(>2500 \mathrm{M})$, lower temperatures and lower rainfall. Likewise, the Hill region is characterized by moderate elevation (500-2500 M), a subtropical to warm temperate climate, and higher annual rainfall. On the other hand, lower elevation $(<500 \mathrm{M})$, sub-tropical to tropical climate and medium rainfall characterize the Plain region.

A doubling (102\%) of fertilizer consumption recorded in south Asia was due primarily to rapid growth in Bangladesh (150\%), India (110\%), and Nepal (200\%); Pakistan (74\%) came a 
little behind. More modest rates of growth were recorded in Sri Lanka $(20 \%)$ and Afghanistan (11\%). In Myanmar, on the other hand, a $45 \%$ reduction in fertilizer consumption took place. The reduction here and the limited growth in Afghanistan could be attributed to the prevailing disturbed political situation. Sri Lanka's smaller growth may also reflect the fact that the level of fertilizer use there $(136 \mathrm{~kg} / \mathrm{ha})$ is already high for the crops grown (Table 3).

Compared to 1965, when fertilizer use accounted for $0-6 \%$ of the total agricultural production in Bangladesh, India, Nepal, and Pakistan, and $43 \%$ in Sri Lanka, fertilizer dependence had grown to $24-52 \%$ in 1990 . This might reach $39-54 \%$ by the year 2000 . Thus, by that time, about one-third to half of the total agricultural production needed in south Asia will have to be obtained by using fertilizers (Ahmed, 2008).

\section{METHODOLOGY}

The data required in this study has been compiled from various secondary sources published by Government and non-Government agencies of Nepal. Area, production and yield data of major food (Paddy, Maize, and Wheat) and vegetable crops were used to find out the production value and agricultural land use changes in different agro-ecological regions from 1995 to 2004. Likewise, real price data was calculated by using a GDP deflator taking 1995 as the base year. Whereas, the production value was derived from annual crop price data (standard local currency in Rupees), which was available in FAOSTAT (2005). Analysis of these data made it easy to assess the contribution of agricultural crops to sustainable economic development in agro-ecological regions of Nepal.

\section{RESULTS AND DISCUSSION}

\section{MOUNTAIN AGRO-ECOLOGICAL REGION}

\section{Real Production Value}

Table 3 presents the real production value trends and the annual economic contribution of major food and vegetable crops in the Mountain agro-ecological region from 1995 to 2004. It clearly indicated that the contribution of paddy and vegetable crops was remarkable in 2004 improving by $174 \%$ and 153\% over 1995, respectively. This implies that policy supporting higher yield and better farm gate prices for vegetable crops is appropriate to increase farmers' income in Mountain region. The percentage changes per annum show distinct variation in gross production value in most of the years. This might be due to the higher dependency of agricultural crops on nature.

\section{Agricultural Land Use Changes and Price}

Table 4 shows that maize was found to have the highest share of agricultural land use area, covering $39 \%$ of the total area in 1995 . It was followed by wheat (29\%), paddy (27\%) and vegetables (4\%). Similarly, in 2004 maize accounted for the highest share (44\%) followed by paddy $(28 \%)$, wheat $(24 \%)$ and vegetables $(4 \%)$. It should be noted that the percentage shares of maize and paddy area to the total area covered were higher in 2004 than in 1995, while in the case of wheat, the situation was reversed meaning that the percentage share of wheat of the total area was lower in 2004 than 1995. Hence, the dominance of crops scenario was changed in 2004 (Maize-Paddy) as compared to 1995 (Maize-Wheat). This implies that the cultivation of paddy is gradually increasing in the Mountain region. On the other hand, the yield of major food and vegetable crops was 
almost stagnant during this period. The yield of paddy, maize, wheat and vegetables increased by only 14\%,11\%,16\% and 17\%, respectively from 1995 to 2004 .

Table 3. Real production value of major food and vegetable crops in the mountain agro-ecological region (NRs. in million) (FAOSTAT, 2005; MOAC, 2005)

\begin{tabular}{c|cc|cc|cc|cc|cc}
\hline Year & \multicolumn{2}{|c|}{ Paddy } & \multicolumn{2}{|c|}{ Maize } & \multicolumn{2}{c|}{ Wheat } & \multicolumn{2}{c|}{ Vegetable } & Total \\
\cline { 2 - 7 } & Value & $\begin{array}{c}\text { \% } \\
\text { Share* }\end{array}$ & Value & $\begin{array}{c}\text { Annual } \\
\text { Change } \\
\text { Share* }\end{array}$ & Value & $\begin{array}{c}\% \\
\text { Share* }\end{array}$ & Value & $\begin{array}{c}\% \\
\text { Share* }\end{array}$ & & \\
\hline 1994 & 404 & 23 & 669 & 38 & 337 & 19 & 353 & 20 & 1764 & 0 \\
1995 & 482 & 25 & 761 & 39 & 352 & 18 & 359 & 18 & 1953 & 30 \\
1996 & 522 & 29 & 564 & 31 & 382 & 21 & 354 & 19 & 1822 & 16 \\
1997 & 572 & 27 & 584 & 28 & 404 & 19 & 537 & 26 & 2096 & 12 \\
1998 & 459 & 25 & 560 & 30 & 360 & 19 & 475 & 26 & 1853 & -8 \\
1999 & 558 & 25 & 747 & 33 & 433 & 19 & 531 & 23 & 2269 & 27 \\
2000 & 580 & 24 & 872 & 36 & 477 & 19 & 518 & 21 & 2446 & 3 \\
2001 & 619 & 23 & 923 & 34 & 491 & 18 & 665 & 25 & 2699 & 11 \\
2002 & 691 & 26 & 977 & 37 & 476 & 18 & 525 & 20 & 2668 & 16 \\
2003 & 698 & 26 & 996 & 36 & 471 & 17 & 564 & 21 & 2730 & 4 \\
\hline
\end{tabular}

*out of total production in the particular year

Table 4. Agricultural land use changes and real price of major food and vegetable crops in 1995 and 2004 (MOAC, 2005; MOF, 2004)

\begin{tabular}{l|lll|lll|ll}
\hline \multicolumn{1}{c|}{ Crops } & \multicolumn{3}{|c|}{1995} & \multicolumn{3}{c|}{2004} & \multicolumn{2}{c}{$\begin{array}{c}\text { Change \% } \\
\text { (1995-2004) }\end{array}$} \\
\cline { 2 - 9 } & $\begin{array}{l}\text { Agri Land } \\
\text { Use(000 } \\
\text { ha) }\end{array}$ & $\begin{array}{l}\text { Yield } \\
\text { (t/ha) }\end{array}$ & $\begin{array}{l}\text { Price* } \\
\text { (Rs./ton) }\end{array}$ & $\begin{array}{l}\text { Agri Land } \\
\text { Use (000 } \\
\text { ha) }\end{array}$ & $\begin{array}{l}\text { Yield } \\
\text { (t/ha) }\end{array}$ & $\begin{array}{l}\text { Price* } \\
\text { (Rs./ton) }\end{array}$ & $\begin{array}{l}\text { Agri } \\
\text { Land Use }\end{array}$ \\
\hline Paddy & $41(27)$ & 1.8 & 5540 & $56(28)$ & 2.0 & 6144 & 37 & 11 \\
Maize & $60(39)$ & 1.6 & 7080 & $89(44)$ & 1.7 & 6463 & 47 & -9 \\
Wheat & $45(29)$ & 1.3 & 5880 & $49(24)$ & 1.5 & 6424 & 11 & 9 \\
Vegetable & $7(4)$ & 8.1 & 6412 & $9(4)$ & 9.5 & 6822 & 28 & 6 \\
Total & $153(100)$ & - & 6228 & $203(100)$ & - & 6463 & 33 & 4 \\
\hline
\end{tabular}

* Calculated by using Agricultural GDP Deflator as base year 1995. Figures in parentheses express the crop area in percentage of total agricultural land area.

\section{HILL AGRO-ECOLOGICAL REGION}

\section{Real Production Value}

Table 5 revealed that maize made the largest contribution to the total production value followed by paddy in the Hill agro-ecological region. It is, however, worth noting that, over the years, the percentage share of total production value of vegetables kept increasing as compared to other crops. Moreover, while the production value from other crops increased by nearly two times, there was an almost threefold increase in production value (income) from vegetables during the 1995 to 2004 period of analysis. It clearly 
established that the increased importance of vegetable farming in the Hills of Nepal was a result of the increased consumption and favourable price structure for vegetables. Hence, it can be concluded that despite comparatively less harvested area than other major food crops, vegetables contributed markedly to the gross crop income value, which ultimately will help boost the economic conditions of Hill farmers. On the other hand, production value decreased in some particular years (see Table 5) was due to the unfavourable climatic condition and upsurge in insurgency (Pakyuryal et al., 2005).

Table 5. Real production value of major food and vegetable crops in the hill agro-ecological region (NRs. in Million) (FAOSTAT, 2005; MOAC, 2005)

\begin{tabular}{|c|c|c|c|c|c|c|c|c|c|c|}
\hline \multirow[t]{2}{*}{ Year } & \multicolumn{2}{|c|}{ Paddy } & \multicolumn{2}{|c|}{ Maize } & \multicolumn{2}{|c|}{ Wheat } & \multicolumn{2}{|c|}{ Vegetable } & \multirow{2}{*}{$\begin{array}{l}\text { Total } \\
\text { Value }\end{array}$} & \multirow{2}{*}{$\begin{array}{c}\text { Annual } \\
\text { Change } \\
(\%)\end{array}$} \\
\hline & Value & $\begin{array}{c}\% \\
\text { Share* }\end{array}$ & Value & $\begin{array}{c}\% \\
\text { Share* }\end{array}$ & Value & $\begin{array}{c}\% \\
\text { Share* }\end{array}$ & Value & $\begin{array}{c}\% \\
\text { Share* }\end{array}$ & & \\
\hline 1994 & 4078 & 27 & 6257 & 42 & 1936 & 13 & 2744 & 18 & 15015 & 0 \\
\hline 1995 & 5166 & 28 & 8074 & 41 & 2173 & 12 & 3476 & 19 & 18215 & 32 \\
\hline 1996 & 5292 & 32 & 6074 & 32 & 2429 & 15 & 3475 & 21 & 16374 & -3 \\
\hline 1997 & 5960 & 32 & 6513 & 29 & 2440 & 13 & 4735 & 26 & 18549 & 16 \\
\hline 1998 & 4826 & 30 & 7190 & 33 & 2280 & 14 & 3578 & 22 & 15908 & -2 \\
\hline 1999 & 5760 & 31 & 9084 & 34 & 2533 & 14 & 3888 & 21 & 18494 & 22 \\
\hline 2000 & 5212 & 27 & 9317 & 34 & 2705 & 14 & 4829 & 25 & 19307 & 3 \\
\hline 2001 & 5874 & 27 & 10050 & 31 & 2688 & 12 & 6312 & 29 & 21697 & 17 \\
\hline 2002 & 6088 & 29 & 10802 & 34 & 2794 & 13 & 4877 & 23 & 20796 & 0 \\
\hline 2003 & 6143 & 29 & 11190 & 34 & 2866 & 14 & 4956 & 24 & 21020 & 4 \\
\hline
\end{tabular}

*out of total production in the particular year

\section{Agricultural Land Use Changes and Real Price}

LRMP (1986) reported that of all the agro-ecological regions, the Hills had the highest area covered by maize, which contributed 70\% to total national production. Table 6 shows that

Table 6. Agricultural land use changes and real price of major food and vegetable crops in 1995 and 2004 (MOAC, 2005; MOF, 2004)

\begin{tabular}{l|lll|lll|ll|}
\hline Crops & \multicolumn{3}{|c|}{1994} & \multicolumn{3}{c|}{2003} & \multicolumn{2}{c}{$\begin{array}{c}\text { Change \% } \\
\text { (1994-2003) }\end{array}$} \\
\cline { 2 - 9 } & $\begin{array}{l}\text { Agri Land } \\
\text { Use(000 } \\
\text { ha) }\end{array}$ & $\begin{array}{l}\text { Yield } \\
\text { (t/ha) }\end{array}$ & $\begin{array}{l}\text { Price* } \\
\text { (Rs./ton) }\end{array}$ & $\begin{array}{l}\text { Agri } \begin{array}{l}\text { Land } \\
\text { Use } \\
\text { ha) }\end{array} \\
\text { (000 }\end{array}$ & $\begin{array}{l}\text { Yield } \\
\text { (t/ha) }\end{array}$ & $\begin{array}{l}\text { Price* } \\
\text { (Rs./ton) }\end{array}$ & $\begin{array}{l}\text { Agri } \\
\text { Land } \\
\text { Use }\end{array}$ & Price \\
\hline Paddy & $338(29)$ & 2.2 & 5540 & $383(30)$ & 2.6 & 6144 & 13 & 11 \\
Maize & $543(47)$ & 1.6 & 7080 & $578(45)$ & 1.9 & 6463 & 7 & -9 \\
Wheat & $230(20)$ & 1.4 & 5880 & $242(19)$ & 1.9 & 6424 & 5 & 9 \\
Vegetable & $50(4)$ & 8.6 & 6412 & $68(5)$ & 10.6 & 6822 & 37 & 6 \\
Total & $1161(100)$ & - & 6228 & 1271 & - & 6463 & 10 & 4 \\
\hline
\end{tabular}

* Calculated by using Agricultural GDP Deflator as base year 1995. Figures in parentheses express the crop area in percentage of total agricultural land area. 
maize was found to have the highest share of the total area of major food and vegetable in 1995 . It was followed by paddy (29\%), wheat $(20 \%)$ and vegetables $(4 \%)$. Similarly, in 2004 maize accounted for the highest share (45\%) followed by paddy (30\%), wheat (19\%) and vegetables $(5 \%)$. It was observed that the percentage shared by maize, paddy and wheat area of the total area covered was changed in 2004 as compared to that in 1995, while the dominant crops scenario was the same (Maize-Paddy) during that period in the region. In 2004, the yield of paddy, maize, wheat and vegetable crops increased by $20 \%$, $16 \%, 29 \%$ and $24 \%$ over 1995 , respectively.

\section{3) PLAIN AGRO-ECOLOGICAL REGION}

\section{(i) Real Production Value}

Paddy, which is one of the major crops of Nepal, is the main crop grown in the Plain region. Table 7 showed that the gross production value substantially increased from 1995 to 2004 , It is notable that an emphatic growth in the production value was observed in paddy followed by wheat and vegetable crops between 1995 and 2004. This clearly indicates that despite comparatively less harvested area than maize and wheat crops, vegetables had a considerable contribution to the gross crop income value in the Plain region.

Table 7. Real production value of major food and vegetable crops in the plain agro-ecological region (NRs. in Million) (FAOSTAT, 2005; MOAC, 2005)

\begin{tabular}{|c|c|c|c|c|c|c|c|c|c|c|}
\hline \multirow[t]{2}{*}{ Year } & \multicolumn{2}{|c|}{ Paddy } & \multicolumn{2}{|c|}{ Maize } & \multicolumn{2}{|c|}{ Wheat } & \multicolumn{2}{|c|}{ Vegetable } & \multirow{2}{*}{$\begin{array}{l}\text { Total } \\
\text { Value }\end{array}$} & \multirow{2}{*}{$\begin{array}{c}\text { Annual } \\
\text { Change } \\
(\%)\end{array}$} \\
\hline & Value & $\begin{array}{c}\% \\
\text { Share* }\end{array}$ & Value & $\begin{array}{c}\% \\
\text { Share* }\end{array}$ & Value & $\begin{array}{c}\% \\
\text { Share* }\end{array}$ & Value & $\begin{array}{c}\% \\
\text { Share* }\end{array}$ & & \\
\hline 1994 & 11617 & 27 & 2293 & 42 & 3264 & 13 & 4671 & 18 & 21845 & 0 \\
\hline 1995 & 16888 & 28 & 2721 & 41 & 3918 & 12 & 5372 & 19 & 28900 & 32 \\
\hline 1996 & 17974 & 32 & 1958 & 32 & 4409 & 15 & 5263 & 21 & 29605 & -3 \\
\hline 1997 & 18621 & 32 & 1970 & 29 & 3889 & 13 & 7350 & 26 & 31830 & 16 \\
\hline 1998 & 14629 & 30 & 1863 & 33 & 4220 & 14 & 6169 & 22 & 26881 & -2 \\
\hline 1999 & 19280 & 31 & 2084 & 34 & 4860 & 14 & 6968 & 21 & 33192 & 22 \\
\hline 2000 & 17802 & 27 & 2066 & 34 & 4802 & 14 & 7051 & 25 & 31721 & 3 \\
\hline 2001 & 19863 & 27 & 2185 & 31 & 5204 & 12 & 9543 & 29 & 36795 & 17 \\
\hline 2002 & 18595 & 29 & 2074 & 34 & 5382 & 13 & 6911 & 23 & 32962 & 0 \\
\hline 2003 & 20535 & 29 & 2226 & 34 & 5574 & 14 & 7375 & 24 & 35709 & 4 \\
\hline
\end{tabular}

*out of total production in the particular year

\section{Agricultural Land Use Changes and Real Price}

Table 8 shows that the percentage share of paddy area of the total area covered were slightly higher in 2004 than 1995, while, in the case of wheat and maize the situation was reversed. However, the dominant crops scenario (Paddy-Wheat) was the same in the 1995 and 2004. Unlike other agro-ecological regions, the yield of paddy, wheat and vegetable crops increased distinctly by $41 \%, 46 \%$, and $30 \%$, respectively, while maize yield increased only by $7 \%$ from 1995 to 2003. 
Table 8. Agricultural land use changes and real price of major food and vegetable crops in 1995 and 2004 (MOAC, 2005; MOF, 2004)

\begin{tabular}{|l|c|c|c|c|c|c|c|c|}
\hline Crops & \multicolumn{3}{|c|}{1994} & \multicolumn{3}{c|}{2003} & \multicolumn{2}{|c|}{$\begin{array}{c}\text { Change \% } \\
\text { (1994-2003) }\end{array}$} \\
\cline { 2 - 9 } & $\begin{array}{c}\text { Agri Land } \\
\text { Use(000 } \\
\text { ha) }\end{array}$ & $\begin{array}{c}\text { Yield } \\
\text { (t/ha) }\end{array}$ & $\begin{array}{c}\text { Price* } \\
\text { (Rs./ton) }\end{array}$ & $\begin{array}{c}\text { Agri Land } \\
\text { Use (000 } \\
\text { ha) }\end{array}$ & $\begin{array}{c}\text { Yield } \\
\text { (t/ha) }\end{array}$ & $\begin{array}{c}\text { Price* } \\
\text { (Rs./ton) }\end{array}$ & $\begin{array}{c}\text { Agri } \\
\text { Land } \\
\text { Use }\end{array}$ & Price \\
\hline Paddy & $989(62)$ & 2.1 & 5540 & $1121(64)$ & 3.0 & 6144 & 13 & 11 \\
Maize & $169(11)$ & 1.9 & 7080 & $168(10)$ & 2.1 & 6463 & 0 & -9 \\
Wheat & $350(22)$ & 1.6 & 5880 & $374(21)$ & 2.3 & 6424 & 7 & 9 \\
Vegetable & $84(5)$ & 8.7 & 6412 & $96(5)$ & 11.3 & 6822 & 14 & 6 \\
Total & 1592 & - & 6228 & 1759 & - & 6463 & 11 & 4 \\
& $(100)$ & & & $(100)$ & & & & 4 \\
\hline
\end{tabular}

* Calculated by using Agricultural GDP Deflator as base year 1995. Figures in parentheses express the crop area in percentage of total agricultural land area.

\section{CONCLUSIONS}

The results indicate that from 1994 to 2003, the proportionate increase in area was the highest in the Mountain region followed by Hill and Plain, while proportionate increases in yield, production and production value were highest in the Plain region followed by the Hill and the Mountain regions for both major food and vegetable crops. Vegetable expansion in the three agro-ecological regions was mainly due to the high vegetable consumption by an increased population and also to the effects of the 20-year Agriculture Prospective Plan.

The Plain and Hill regions are envisaged as more appropriate for the cultivation of major food and vegetable crops than the Mountain region. Maize dominated cropping systems were found in the Mountain and Hill regions, whereas, paddy dominated the cropping system in the Plain region. During the 1995 to 2004 period, cropping patterns were changed slightly in the Mountain region from Maize-Wheat to Maize-Paddy, while they did not significantly change in other regions during the past decade. Despite smaller harvested area, the contribution of vegetables to gross production value was remarkable in all three regions. This implies that vegetable crops are one of the most important and potential sources of farm income. The importance of vegetables is particularly high in the hill and mountain regions, as the yield of major food crops is significantly lower in these regions. Improved access to and availability of agricultural inputs is key to improving the production and yield of major food and vegetable crops to provide sustainable economic development in the country.

\section{REFERENCES}

CBS, 2005. Nepal in figures 2005. Central Bureau of Statistics, Nepal.

CBS, 2007. An assessment of poverty in Nepal 1994/95 to 2003/04. Central Bureau of Statistics, Nepal.

FAO, 1998. Asia's women in agriculture, environment and rural production: Nepal. Sustainable Development Department of Food and Agriculture Organization of the United Nations, Regional Office for Asia and Pacific, Bangkok, Thailand. 
FAO, 2005. Statistical Database CD-ROM, Vol.2. Food and Agriculture Organization of the United Nations, Rome.

IFA/IFDC/PPI/IPI/FAO, 2002. Fertilizer use by crop, fifthe edition pp. 9-43. International Fertilizer Industry Association (IFA)/ International Fertilizer Development Centre (IFDC)/ Phosphate and Potash Institute (PPI)/International Potash Institute (IPI) and Food and Agriculture Organization of the United Nations (FAO).

LRMP, 1986. Land utilization report. The Land Resource Mapping Project, Kenting Earth Sciences, Canada and Government of Nepal.

MOAC, 2005. Statistical Information on Nepalese Agriculture (Time Series Information). Ministry of Agriculture and Cooperatives, Nepal.

MOF, 2005. Economic Survey 2003/2004. Ministry of Finance, Nepal.

Pariyar, D., 2005. Country pasture and forage resource profiles: Nepal. Food and Agriculture Organization of United Nations, Rome.

Pyakuryal, B., Y.B. Thapa and D. Roy, 2005. Trade liberalization and food security in Nepal. MTID Discussion Paper No.88, pp.46-47. International Food Policy Research Institue (IFPRI), Washington, USA.

Saleem Ahmed, 2008. Food and Fertilizer Technology Center. Available in: http://www.agnet.org/library/eb/387/ (March 2009).

World Bank, 2004. World development indicators CD-ROM. World Bank, 2004. 